\title{
Observations on arbuscular mycorrhiza associated with important edible tuberous plants grown in wet evergreen forest in Assam, India
}

\author{
RAJESH KUMAR ${ }^{1, \boldsymbol{\bullet}}$, ASHWANI TAPWAL ${ }^{2}$, SHAILESH PANDEY $^{1}$, RAJA RISHI $^{\mathbf{1}}$ DEVAPOD BORAH $^{1}$ \\ ${ }^{1}$ Rain Forest Research Institute, P.O. 136, Jorhat 785001, Assam, India. Tel.: +91-0376-2305106, ’e-mail: rajeshicfre@ gmail.com \\ ${ }^{2}$ Forest Research Institute, Dehradun 248006, Uttrakhand, India
}

Manuscript received: 9 May 2013. Revision accepted: 16 July 2013.

\begin{abstract}
Kumar R, Tapwal A, Pandey S, Rishi R, Borah D. 2013. Observations on arbuscular mycorrhiza associated with important edible tuberous plants grown in wet evergreen forest in Assam, India. Biodiversitas 14: 67-72. Non-timber forest products constitute an important source of livelihood for rural households from forest fringe communities across the world. Utilization of wild edible tuber plants is an integral component of their culture. Mycorrhizal associations influence the establishment and production of tuber plants under field conditions. The aim of present study is to explore the diversity and arbuscular mycorrhizal (AMF) colonization of wild edible tuber plants grown in wet evergreen forest of Assam, India. A survey was conducted in 2009-10 in Sunaikuchi, Khulahat, and Bura Mayong reserved forest of Morigaon district of Assam to determine the AMF spore population in rhizosphere soils and root colonization of 14 tuberous edible plants belonging to five families. The results revealed AMF colonization of all selected species in all seasons. The percent colonization and spore count was less in summer, moderate in winter and highest in rainy season. Seventeen species of arbuscular mycorrhizal fungi were recorded in four genera viz. Acaulospora (7 species), Glomus (5 species), Sclerocystis (3 species) and Gigaspora (2 species).
\end{abstract}

Key words: AMF, root colonization, wild edible tuber

\section{INTRODUCTION}

Wild edible plants refer to species that are neither cultivated nor domesticated, but available from their natural habitat and used as source of food (Beluhan and Ranogajec 2010). They are collected by forest fringe communities for their requirement of food and livelihoods. Earlier works have reported the wild edible plants as a potential source of nutrition and many of them have higher nutrition than conventionally eaten crops (Grivetti and Ogle 2000). Arbuscular mycorrhizal fungi (AMF) colonize the roots of higher plant as obligate symbionts, where the host generally benefited through increased nutrient uptake, improved growth and better survival (Linderman 1994; Akhtar and Siddiqui 2007; Smith and Read, 2008). Soil is characterized by the presence of a diverse population of microorganisms of which mycorrhizal fungi constitutes one of important component. Arbuscular mycorrhizal (AM) fungi are the most common types among all mycorrhizae and represent a major group of soil microbial community (Linderman 1992). Arbuscular Mycorrhiza is a widespread mutualistic symbiosis between land plants and fungi belonging to the phylum Glomeromycota. Their occurrence as root symbionts has been reported from exceptionally wide range of plants (Sharma et al. 2007). The AMF association may also increase the tolerance of host plant against biotic (Hol and Cook 2005; Akhtar and Siddiqui 2007) and abiotic stresses, including salinity and drought (Cartmill et al. 2007). In modern years, AM fungi gained considerable importance in horticulture, agriculture, afforestation and land reclamation (Javot et al. 2007) because of their potentially to improve growth and yield of the plants by increasing the nutrient uptake (Jensen 1984). AM fungal association found in all organs of plants which are concerned with the absorption of substances from the soil (Srivastava et al. 1996). The occurrence of AM fungi association with the portions other than roots was reviewed by Nazim (1990). Presence of AM association has been reported in tubers of Pueraria tuberosa (Willd.) DC (Rodrigues 1996), Colocasia esculenta (L.) Scott (Bhat and Kaveriappa 1997), garlic bulbs (Kunwar et al. 1999) and tubers of Gloriosa superba L. (Khade and Rodrigues 2003). AMF colonization varies with season and its effects also influence the establishment of plants under field condition (Giovannetti and Nicolson 1983). Information on AM association with tuberous plants is scanty. Therefore, the present study is aimed to determine the AMF spore population in rhizosphere soils and its colonization for wild edible tuberous plants during different seasons in Sunaikuchi, Khulahat and Bura Mayong reserve forest of Morigaon district in Assam, India.

\section{MATERIALS AND METHODS}

\section{Study area}

The Sunaikuchi, Khulahat, and Bura Mayong Reserved Forests are situated in Morigaon district of Assam, India 
between $26.15^{\circ}$ to $26.5^{\circ}$ Northern latitude and $92^{\circ}$ to $95.5^{\circ}$ Eastern longitude (Figure 1). These three Reserved Forest, (RF) of Morigaon district formed under Assam Forest Regulation Act, 1891. The area receives annual rainfall is about $1530.9 \mathrm{~mm}$ and the annual average maximum temperature is $30.4^{\circ} \mathrm{C}$ and the minimum is $19.8^{\circ} \mathrm{C}$. Fringe area of the RF is inhabited by a few ethnic groups such as Karbis, Bodos, Kukis, Dimasas, Hmars, Garos, Rengma Nagas and Tiwas. These communities are dependent on forest for habitat and other needs for well-being; the forest contributes livelihoods to many households as well.

\section{Target species}

The root and rhizosphere soil samples of 14 wild edible tuberous plants belonging to five families were collected viz; Ipomoea batatas (L.) Lam., Pueraria thomsonii Benth., Pueraria tuberosa (Wild.) D.C, Vigna vexillata (L.) Rich., Alocasia odora (Roxb.) C. L. Koch, Alocasia cucullata Schott., Colocasia esculenta (L.) Schott., Sagittaria sagittifolia L., Amorphophallus campanulatus Roxb., Dioscorea pentaphylla L., Dioscorea puber (B1.), Dioscorea alata L., Dioscorea esculenta Burk., Dioscorea batatas Decene (Figure 2), belonging to four families Fabaceae, Araceae, Araceae and Dioscoreaceae respectively) and studied.

\section{AMF spore isolation, enumeration and identification}

A total of 150 soil samples were collected from the rhizosphere of 14 plants species having tuber from a depth of 5-30 cm during mid-May, late July, and early September

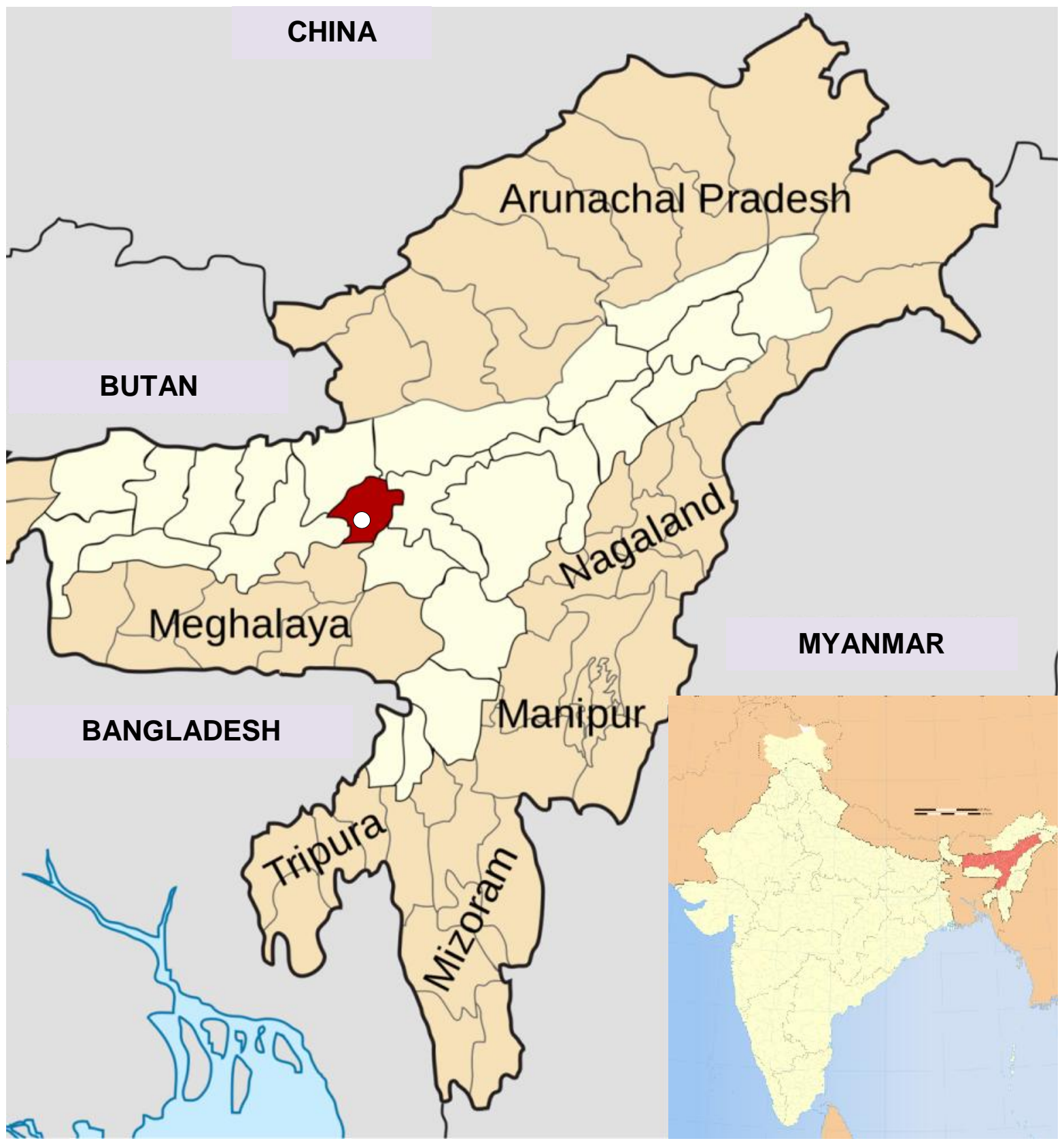

Figure 1. Study sites at Sunaikuchi, Khulahat and Bura Mayong Reserved Forests $(\bullet)$ in Morigaon district of Assam, India 


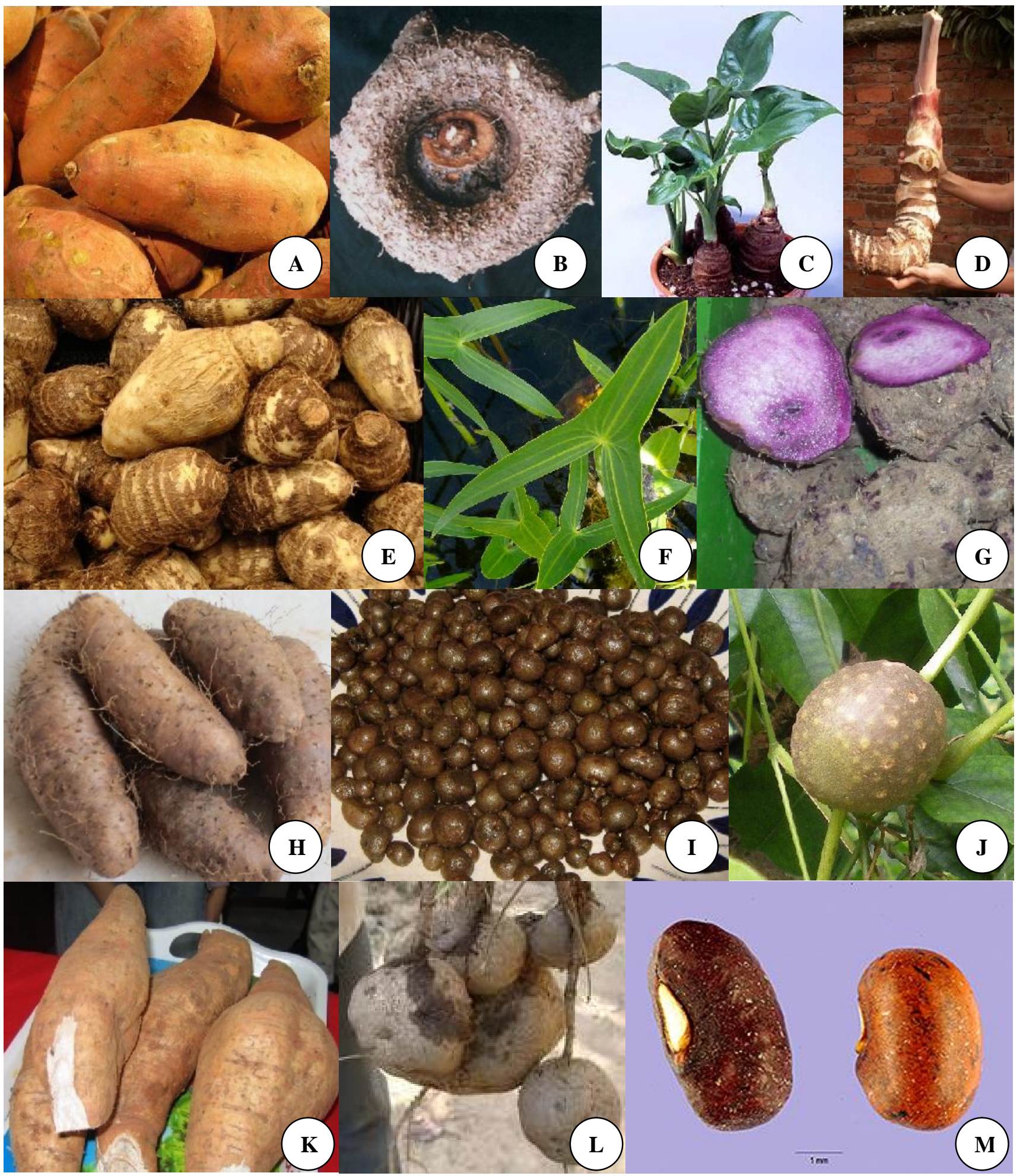

Figure 2. A. Ipomoea batatas, B. Amorphophallus campanulatus, C. Alocasia cucullata, D. Alocasia odora, E. Colocasia esculenta, F. Sagittaria sagittifolia, G. Dioscorea alata, H. Dioscorea esculenta, I. Dioscorea batatas, J. Dioscorea pentaphylla, K. Pueraria thomsoni, L. Pueraria tuberosa, M. Vigna vexillata (photos from many sources).

in 2009-10. The samples (about $500 \mathrm{~g}$ for each) were airdried for 2 weeks and stored in sealed plastic bags at $4^{\circ} \mathrm{C}$. AMF were isolated by a wet sieving and decanting technique (Gerdemann and Nicholson 1963; An et al. 1990; Singh and Tiwari 2001). Fifty grams of soil was suspended in $250 \mathrm{ml}$ of water, stirred with a magnetic stirrer for 10 min and sieved. Spores and debris were collected on 150 , 100, 70 and $40 \mathrm{~m}$ sieves under tap water, filtered through Whatman filter paper and placed in a $90 \mathrm{~mm}$ Petri-dish for examination under a binocular stereomicroscope (Olympus BX 50F4, Japan). Each type of AMF spore was sequentially mounted in water, lactophenol, Poly vinyl 
alcohol and Melzer's reagent (Morton 1988; Morton and Benny 1990) for identification. The spores were identified up to the species level with the help of a VAM fungi identification manual (Schenck and Perez 1990). The identification was based on spore color, size, surface ornamentation and wall structure with reference to the descriptions and pictures provided by the International Collection of Vesicular and Arbuscular Mycorrhizal Fungi (http://invam.caf.wvu.edu) and originally published species descriptions.

\section{Analysis of AMF and DSE colonization}

Roots were washed thoroughly in tap water and cut into approximately $1 \mathrm{~cm}$ long segments. The roots were cleared in $10 \%(\mathrm{w} / \mathrm{v}) \mathrm{KOH}$ by heating at $90^{\circ} \mathrm{C}$ for 1 to $2 \mathrm{~h}$, depending on the degree of lignifications of the roots, then washed and stained with stamp pad ink (Das and Kayang 2008). The stained root samples were mounted on slides and examined for AM colonization under a light microscope. The colonization of root length with arbuscules, vesicles, hyphae and dark septate endophytes per sample were quantified by the magnified intersections method (McGonigle et al. 1990). Percent root colonization was determined using the following formula:

$$
\% \text { Root colonization }=\frac{\text { No. of positive segments }}{\text { No. of segments observed }} \times 100
$$

\section{RESULTS AND DISCUSSION}

Five-hundred and eighteen arbuscular mycorrhizal fungal spore samples were wet-sieved from the 150 soil samples. Seventeen species of arbuscular mycorrhizal fungi were identified. The morphological characters of some identified arbuscular mycorrhizal fungi are illustrated in (Table 1). All the fourteen plant species studied exhibited AM fungal association. AMF colonization in roots and the spore population in the rhizosphere soil samples of all fourteen plant species having tubers showed wide range of variation under different seasons (Table 1). The level of AM fungal association depends on root morphology, metabolism and rate of plant growth (Warmer et al. 1980). Percent root colonization and mycorrhizal spore counts steadily increased in rainy season. Earlier reports also revealed higher percent root colonization during rainy season (Raghupathy and Mahadevan 1993; Kumar et al. 2013). The maximum infection $(73 \%)$ was recorded in Sagittaria sagittifolia whereas minimum infection (45\%) in Amorphophallus campanulatus were observed during rainy season in 2009-10. However, the maximum percent colonization was $(53 \%)$ in Vigna vexillata in winter and $(51 \%)$ in summer only. In the present study, the percent root colonization recorded higher in rainy season than in winter and summer. Least activity of AM fungi in other seasons may be due to reduced translocation of carbohydrates towards the roots. The spore population was also least in summer and gradually increased in July. The spore population varied from 15-61 spores, 13-41 spores and 7-27 spores during rainy, winter and summer seasons respectively (Table 2). Khade and Rodrigues (2007) also observed maximum number of spore density while studying the occurrence of AM fungi in plants with underground storage organs. The identified species of arbuscular mycorrhizal fungi belonged to the genera of Acaulospora (7 species), Glomus (5 species), Sclerocystis (3 species) and Gigaspora (2 species).The occurrence frequency of the five genera was $42.62 \%, 36.67 \%, 12.92 \%$, and $7.71 \%$, respectively (Table 2). The results indicated that Acaulospora and Glomus were the dominant genera, and A. denticulata, A. spinosa, A. tuberculata, G. clarum, $G$. constrictum and G. monosporum and S. clavispora were the dominant species (Table-3). It is also observed that Acaulospora and Glomus species usually produce more spores than Gigaspora and Sclerocystis species in the same environment. This may be due to their smaller spore size and require a short time to produce spores (Hepper 1984; Bever et al. 1996).

Table 1. Important wild edible plants with tubers in Sunaikuchi, Khulahat, and Bura Mayong Reserved Forest, Assam in 2009-2010 and

\begin{tabular}{|c|c|c|c|c|c|c|c|c|}
\hline \multirow{2}{*}{ Name of plants } & \multirow{2}{*}{ Family } & \multirow{2}{*}{ Local name } & \multicolumn{3}{|c|}{$\%$ root colonization } & \multicolumn{3}{|c|}{ No. of spores/ $50 \mathrm{~g}$ of soil } \\
\hline & & & Rainy & Winter & Summer & Rainy & Winter & Summer \\
\hline Alocasia cucullata Schott. & Araceae & Panchamukhi Kachu & 58 & 33 & 40 & 21 & 19 & 16 \\
\hline Alocasia odora (Roxb.) C.L. Koch & Araceae & Baibing & 66 & 35 & 16 & 44 & 31 & 21 \\
\hline Amorphophallus campanulatus Roxb. & Araceae & Pani kachu & 45 & 32 & 41 & 21 & 18 & 14 \\
\hline Colocasia esculenta $(\mathrm{L})$ Schott. & Araceae & Kachu & 66 & 42 & 34 & 26 & 19 & 18 \\
\hline Sagittaria sagittifolia $\mathrm{L}$. & Araceae & Ole kachu & 73 & 45 & 37 & 38 & 25 & 13 \\
\hline Ipomoea batatas (L.) Lam. & Convolvulaceae & Ranga alu, Mitha alu & 53 & 41 & 22 & 44 & 31 & 14 \\
\hline Dioscorea alata $\mathrm{L}$. & Dioscoreaceae & Kath alu & 62 & 41 & 32 & 26 & 24 & 16 \\
\hline Dioscorea batatas Decene. & Dioscoreaceae & Gosh alu & 66 & 38 & 31 & 39 & 25 & 19 \\
\hline Dioscorea esculenta Burk. & Dioscoreaceae & Mua alu & 58 & 39 & 28 & 15 & 13 & 7 \\
\hline Dioscorea pentaphylla L. & Dioscoreaceae & Paspatia alu & 51 & 40 & 32 & 22 & 18 & 13 \\
\hline Dioscorea puber BL & Dioscoreaceae & Jangali alu & 67 & 38 & 35 & 24 & 23 & 9 \\
\hline Pueraria thomsonii Benth. & Fabaceae & Mayong (Mis), Pani alu & 42 & 35 & 24 & 39 & 32 & 18 \\
\hline Pueraria tuberosa (Wild.) D.C & Fabaceae & Urahi alu & 68 & 44 & 32 & 58 & 33 & 21 \\
\hline Vigna vexillata (L.) Rich & Fabaceae & Bonoria urahi & 72 & 53 & 51 & 61 & 41 & 27 \\
\hline
\end{tabular}
seasonal variation of arbuscular mycorrhizal association in wild edible tuberous plants 


\section{CONCLUSION}

The study revealed that the plants with tubers growing in the tropical wet ever green forest of Sunaikuchi, Khulahat, and Bura Mayong Reserved Forest of Assam, India are colonized by arbuscular mycorrhizal fungi. It is also apparent that rainy season may considered as the best season for the propagation of plants by the application of AMF as bioinoculants even for the plants of rare and threatened species. Our results also revealed that uneven spatial distribution (clumped distribution) of arbuscular mycorrhizal fungal spores and the complex below ground structure of tropical wet ever green forests are major factors that affect the spore density.

\section{ACKNOWLEDGEMENTS}

The authors are thankful to the Indian Council of Forestry Research and Education (ICFRE) for funding the research project No: RFRI13/2008-09/FP.

\section{REFERENCES}

Akhtar MS, and Siddiqui ZA. 2007. Biocontrol of a chickpea root-rot disease complex with Glomus intraradices, Pseudomonas putida and Paenibacillus polymyxa. Aust Plant Pathol 36: 175-180.

An ZQ, Hendrix JW, Hershman DE, and Henson GT. 1990. Evaluation of the most probable number (MPN) and wet-sieving methods for determining soil-borne populations of endogonaceous mycorrhizal fungi. Mycologia 82: 516-581.

Beluhan S, and Ranogajec A. 2010. Chemical composition and nonvolatile components of Crotial wild edible mushrooms. Food Chemistry 124: 1076-1082.

Bever JD, Morton JB, Antonovics J, Schultz PA. 1996. Host-dependent sporulation and species diversity of arbuscular mycorrhizal fungi in a mown grassland. J Ecol 84: 71-82.

Bhat RP, Kaveriappa KM. 1997.Occurrence of vesicular Arbuscular mycorrizal fungi in the tubers of Colocasia esculenta (L.) Schott., Mycorrhiza News 912-13.

Cartmill AD, Alarcon A, Valdez-Aguilar LA. 2007. Arbuscular mycorrhizal fungi enhance tolerance of Rosa multiflora cv. Burr to bicarbonate in irrigation water. J Plant Nutr 30: 1517-1540.

Das P, Kayang H. 2008. Stamp pad ink, an effective stain for observing arbuscular mycorrhizal structure in roots. World J Agric Sci 4: 58-60

Gerdemann JW, Nicolson TH. 1963. Spores of mycorrhizal Endogone extracted from soil by wet sieving and decanting. Trans Br Mycol Soc 46: $235-244$.

Giovannetti M, Nicolson TH. 1983. Vesicular-arbuscular mycorrhizas in Italian sand dunes. Trans Br Mycol Soc 80: 552-557.

Grivetti LE, Ogle BM. 2000. Value of traditional foods in meeting macroand micronutrient needs: the wild plant connection. Nutr Res Rev 13 31-46.

Hepper CM. 1984. Isolation and culture of VA mycorrhizal (VAM) fungi. In: Powell CL, Bagyaraj DJ (eds). VA Mycorrhizae. CRC Press, Florida.
Hol GW, Cook R. 2005. An overview of arbuscular mycorrhizal funginematode interactions. Basic Appl Ecol 6: 489-503.

Javot H, Pumplin N, Harrison MJ. 2007. Phosphate in the arbuscular mycorrhizal symbiosis: transport properties and regulatory roles. Plant Cell Environ 30 (3): 310-322.

Jensen A.1984. Responses of barley, pea and maize to inoculation with different vesicular Arbuscular Mycorrhizal fungi in irradiated soils. Pl Soil 78: 315-323.

Khade SW, Rodrigues BF. 2003. Incidence of Arbuscular Mycorrhizal colonization in tubers of Gloriosa superba L., Mycorrhiza News 15: 14-16.

Khade SW, Rodrigues BF. 2007. Incidence of arbuscular mycorrhizal (AM) fungi in some angiosperms with underground storage organs from Western Ghat region of Goa. Trop Ecol 48 (1): 115-118.

Kumar R, Tapwal A, Jaime A Teixeira da Silva, JA, Pandey S, Borah DP. 2013. Biodiversity of arbuscular mycorrhizal fungi associated with mixed natural forest of Jeypore, Assam. Bioremed Biodiv Bioavail 7 (1): 91-93.

Kunwar IK, Reddy PJM, Manoharachary C. 1999. Occurrence and distribution of AMF associated with garlic rhizosphere soil. Mycorrhiza News 11: 4-6.

Linderman RG. 1992. Vesicular-arbiscular mycorrhizae and soil microbial interactions, In: Bethlenfalvay GJ, Linderman RG (eds). Mycorrhizae in sustainable agriculture. Soil Science Society of America, Madison, WI.

Linderman RG. 1994. Role of VAM fungi in biocontrol. In: Pfleger FL, Linderman RG (eds). Mycorrhizae and plant health. The American Phytopathological Society, St. Paul, Minnesota.

McGonigle TP, Miller MH, Evans DG, Fairchild GL, Swan JA. 1990. A new method which gives an objective measure of colonization of roots by vesicular arbuscular mycorrhizal fungi. New Phytol 115: 495-501.

Morton JB. 1988. Taxonomy of VA mycorrhizal fungi: classification, nomenclature, and identification. Mycotaxon 37: 267-324.

Morton JB, Benny GL. 1990. Revised classification of arbuscular mycorrhizal fungi (Zygomycetes), a new order Glomales, two new suborders Glomineae and Gigasporinae and two new families Acaulosporaceae and Gigasporaceae with an emendation of Glomaceae. Mycotaxon 37: 471-479. 
Nazim G. 1990.Vesicular Arbuscular Mycorrhiza in portions other than roots. In: Jalali BL, Chand H (eds). Current Trends in Mycorrhiza Research. Sankat Mochan Art Press, Hisar, India.

Raghupathy S. Mahadevan A.1993. Distribution of vesicular Arbuscular mycorrhizae in plants and rhizosphere soils of the tropical plains, Tamilnadu, India. Mycorrhiza 3: 123- 136.

Rodrigues BF. 1996. Occurrence of VAM fungi in the tubers of Pueraria tuberosa (Willd.) DC. Mycorrhiza News 8-9.

Schenck NC, Perez Y. 1990. Manual for the Identification of VA Mycorrhizal Fungi ( $2^{\text {nd }}$ End $)$, International Culture Collection of VA Mycorrhizal Fungi (INVAM), University of Florida, Gainesville, FL.
Sharma S, Aggarwal A, Kaushish S. 2007. Biodiversity of endomycorrhizal fungi associated with some medicinally important plants of Himachal Pradesh. J Indian Bot Soc 86: 14-17.

Singh SS, Tiwari SC. 2001. Modified wet-sieving and decanting technique for enhanced recovery of spores of vesicular-arbuscular mycorrhizal (VAM) fungi in forest soils. Mycorrhiza News 12: 12-13.

Smith SE, Read DJ. 2008. Mycorrhizal Symbiosis. $3^{\text {rd }}$ ed. Academic Press, London.

Srivastava D, Kapoor R, Srivastava SK, Mukerji KG. 1996. Vesicular arbuscular mycorrhiza-an overview In: Mukerji KG (ed). Concepts in Mycorrhizal Research. Kluwer, Netherlands.

Warner A, Mosse B. 1980. Independent spread of Vesicular Arbuscular Mycorrhizal fungi in soil. Trans Br Mycol Soc 74: 407-410. 